\title{
PEMANFAATAN SISTEM INFROMASI GEOGRAFI UNTUK PEMODELAN SPASIAL PENGEMBANGAN WISATA PANTAI DI KABUPATEN TULUNGAGUNG
}

\author{
Purwanto, I Komang Astina, Yusuf S \\ Universitas Negeri Malang \\ E-mail: purwanto.fis@um.ac.id; komang.astina.fis@um.ac.id; \\ yusuf.suharto.fis@um.ac.id
}

\begin{abstract}
Abstrak: Tujuan dalam dalam penelitian ini yaitu mengkaji kesesuaian lahan untuk wisata pantai dan menentukan prioritas pengembangan pantai di Kabupaten Tuluangung. Penelitian ini merupakan penelitian survey dengan menggunakan analisis Sistem Informasi Geografi yaitu pemodelan spasial dengan cara skoring. Analisis dilakukan dalam dua tahap yaitu tahap I untuk mencari pantai yang sesuai untuk wisata, dan tahap II untuk mencari pantai yang paling prioritas untuk dikembangkan. Hasil penelitian menunjukkan bahwa dari 10 pantai di Kabupaten Tulungagung sebanyak 8 (delapan) pantai memiliki tingkat kesesuain S1 yaitu sesuai dan 2 pantai S2 (sesuai dengan faktor pembatas). Dari pantai yang sesuai tersebut dianalisis lebih lanjut untuk mempeoleh pantai yang paling prioritas untuk dikembangkan. Hasil analisis tahap II pantai yang paling Prioritas untuk dikembangkan yaitu pantai Bayem, Klatak, dan Gerangan. Ketiga pantai tersebut memiliki skor 290, 275, dan 260. Skor yang tinggi menunjukkan bahwa pantai tersebut memiliki potensi yang besar untuk dikembangkan menjadi tempat wisata. Sedangkan pada Prioritas II yaitu pantai Sidem, dan Prioritas III pantai Brumbun, Nglarap, Sine, dan Gemah.
\end{abstract}

Kata Kunci: SIG, Pemodelan Spasial, Pengembangan

\section{PENDAHULUAN}

Pariwisata merupakan salah satu industri gaya baru yang mampu menyediakan pertumbuhan ekonomi yang cepat dalam hal kesempatan kerja, pendapatan, taraf hidup dan mengaktifkan sektor produksi lain. Seiring dengan peningkatan kesadaran masyarakat terhadap kualitas hidup, maka dalam perkembangannya kebutuhan rekreasi dan pariwisata banyak mengalami perubahan orientasi.

Wisata pantai saat ini telah menjadi salah satu primadona tujuan wisata baik dari mancanegara maupun domestik. Peluang ini telah menjadi inpirasi daerah yang memiliki kekayaan pantai dan laut berusaha untuk melakukan eksplorasi potensi tersebut.Pengembangan wisata pantai sebagai alternative ekonomi marsyarakat dan pengembangan wilayah pesisir sampai saat ini masih menghadapi sejumlah kendala yang harus segera diselesaikan.

Dalam pengembangan wilayah
pesisir haruslah jelas tujuannya,


kemudian ditentukan sifat pantainya dan kemudian dibuat arahan penggunaan ruang dengan mendasarkan kondisi fisik, menentukan orientasi dan kemampuan masyarakat dalam arti mengetahui daya tampung dan kemampuan masyarakat. Selanjutnya harus ditentukan potensi ekonomi masyarakat hal ini terutama untuk mengetahui orientasi dan fungsi wilayah harus ditentukan berdasarkan tipologi, aspirasi, dan partisipasi masyarakat perlu diketahui. Setelah semua faktor diketahui baru dibuat rencana tata ruang (Sunarto, et.al, 2002). Optimalisasi pengembangan wisata pantai harus direncanakan secara matang dan keterpaduan dalam konsep wilayah kepesisiran.

Menurut CERC (1984), yang dimaksud dengan pantai ialah jalur sempit daratan pada pertemuan dengan laut, meliputi daerah di antara garis air tinggi dan garis air rendah. Snead (1982) mengemukakan, bahwa pantai merupakan jalur daratan yang membatasi tubuh perairan, yang kadang-kadang tergenang oleh pasang surut atau gelombang. Komar 1976) menyatakan, bahwa pantai yaitu jalur daratan yang membatasi tubuh perairan, baik daratan itu berupa batuan padu ataupun sedimen lepas.
CERC (1984), Snead (1982), dan Komar (1976) menyatakan, bahwa pantai yang material penyusunnya berupa sedimen lepas disebut gisik (beach). Menurut Pethick (1984) dan Komar (1976), gisik umumnya terjadi dari material lepas berukuran pasir atau kerikil. Komar (1976) mengemukakan, bahwa secara etimologis, istilah beach berasal dari sebuah kata dalam bahasa Anglo-Saxon yang berarti kerikil.

Garis batas antara darat dan permukaan laut disebut sebagai garis pantai (shoreline). Garis pantai menandai interaksi antara muka laut dan daratan yang bergeser naik dan turun sesuai dengan pasang dan surut (Snead, 1982 dan CERC, 1984).

Berdasarkan konsep tentang pantai tersebut, dapat diketahui, bahwa pantai memiliki karakteristik sebagai berikut:

(a) pantai berhubungan langsung dengan laut;

(b) pantai berkedudukan di antara garis air tinggi dan garis air rendah;

(c) pantai dapat terjadi dari material padu, lepas, atau lembek;

(d) pantai yang bermaterial lepas dengan ukuran kerikil atau pasir disebut gisik (beach);

(e) pantai dapat berelief rendah (datar, berombak, atau bergelombang), 
namun dapat pula berelief tinggi

(berbukit atau bergunung); dan

(f) pantai secara genetik dapat berasal dari bentukan marin, organik, vulkanik, tektonik, fluviomarin, denudasional, atau solusional.

Kabupaten Tulungagung merupakan salah satu kabupaten yang memiliki potensi wisata pantai yang cukup banyak dan bervariasi. Namun geliat untuk pengembangan objek wisata pantai sampai saat ini belum berkembang dengan baik, bahkan sedikit mengalami kemunduran. Salah satu contoh adalah Pantai Popoh yang berkembang pesat pada tahun 1990-2000 yang menjadi ikon utama wisata pantai di kabupaten Tulungagung. Namun kondisi tersebut berbalik dengan kenyataan saat ini. Sarana dan prasarana yang tidak terurus dengan baik, perubahan fungsi lahan menjadi tempat Pelelangan Ikan menambah ketidaknyamanan pengunjung.

Bertitik tolak dari permasalahan tersebut maka pemerintah kabupaten Tulungagung perlu mengembangkan wisata pantai yang baru yang dapat menjadi andalan industri pariwisata kedepannya. Berdasarkan data Bappeda di Kabupaten Tulungagung Tahun 2012, ada 10 pantai yang berpotensi untuk dikembangkan. Kesepuluh pantai tersebut antara lain: Pantai Popoh, Sidem, Gemah, Bayem, Klatak, Nglarap, Brumbun, Nggerangan, Sine dan Molang.

Perkembangan Teknologi Sistem Informasi Geografi (SIG) saat ini berkembang pesat, baik dari segi perangkat lunak maupun dalam aplikasi. Salah satu manfaat yang SIG yaitu dapat digunakan sebagai dasar dalam pengambilan keputusan baik pemerintah maupun swasta. Kemampuan untuk menganalisis spasial merupakan salah satu kelebihan aplikasi ini. Dengan kemampuan tersebut memungkinkan pengguna untuk melakukan pemodelan. Selain data dengan SIG sebaran spasial dapat dilihat dalam sebuah peta.

Penggunaan sistem computer untuk memecahkan masalah keruangan yang ada dipermukaan bumi saat ini terus meningkat. Fenomena ataupun kejadian yang ada di bumi dimodelkan agar bisa digunakan oleh komputer untuk melakukan perhitungan atau analisa. Sejalan dengan perkembangan teknologi computer, perangkat lunak, dan sistem berbasis data, metode pemodelan dan penyimpanan data spasial juga mengalami perubahan. Salah satu perkembangan tersebut adalah penggunaan Sistem Informasi Geografi. 
SIG saat ini telah banyak digunakan dalam berbagai bidang terkait dengan pengambilan keputusan yang melibatkan data spasial (Keruangan). Kekomplekan data spasial yang ada di lapangan merupakan salah satu kendala yang sering dijumpai oleh pemerintah untuk menentukan kebijakan. Dengan SIG kompleksitas data spasial tersebut dapat di sederhanakan untuk dapat dianalisis secara cepat, tepat, dan akurat. Demikian halnya dengan data kepesisiran dan pantai sebagaimana yang terjadi di Kabupaten Tuluangung.

\section{METODE PENELITIAN}

Jenis penelitian ini adalah deskriptif dengan menggunakan metode survey, yang bertujuan untuk mengkaji karakteristik kesesuaian pariwisata pantai dan mengkaji tingkat prioritas pengembangan. Variabel keruangan yang dianalisis meliputi unsur biotik, abiotik, dan kultural (Budaya). Objek penelitian meliputi 10 pantai di kabupaten Tuluangagung yaitu Pantai Nglarap, Klatak, Bayem, Gemah, Sidem,Popoh, Brumbun, Gerangan, Sine, dan Molang.
Ke sepuluh pantai tersebut akan dikembangkan sesuai dengan Rencana Tata Ruang Wilayah (RTRW) Kabupaten Tulungagung 2010-2029.

Data dikumpulkan dengan cara observasi yaitu pengukuran lapangan tentang aspek fisik, dokumentasi dan wawancara. Data tersebut selanjutnya digunakan sebagai dasar analisis dalam pemodelan spasial. Pemodelan spasial ini dilakukan dengan teknologi SIG. Pemodelan tersebut dilakukan dengan cara memberikan skor pada setiap parameter. Besarnya nilai skor disesuaikan dengan matrik kesesuaian lahan untuk wisata pantai. Setelah diperoleh pantai yang sesuai untuk wisata pantai langkah selanjutnya adalah menentukan prioritas objek wisata yang sesuai tersebut untuk dikembangkan. Skala prioritas ini didasarkan pada pengukuran aspek fisik, sosial, aksesibilitas, yang lebih detil. Model yang dikembangkan masih menggunaka model skoring sengan SIG. Matrik parameter kesesuaian lahan untuk wisata pantai disajikan dalam Tabel 1 . 
16

Pemanfaatan Sistem Informasi Geografi Untuk Pemodelan Spasial

Pengembangan Wisata Pantai Di Kabupaten Tulungagung

Tabel 1. Matriks kesesuaian lahan untuk wisata pantai di Kabupaten Tulungagung

\begin{tabular}{|c|c|c|c|c|c|c|c|}
\hline No & Parameter & $\begin{array}{l}\text { Kategori } \\
\text { S1 }\end{array}$ & Skor & $\begin{array}{l}\text { Kategori } \\
\text { S2 }\end{array}$ & Skor & Kategori N & Skor \\
\hline 1. & $\begin{array}{l}\text { Tipe/Karakteristik } \\
\text { Pantai }\end{array}$ & $\begin{array}{l}\text { Pantai Ber- } \\
\text { pasir }\end{array}$ & 30 & $\begin{array}{l}\text { Pantai Ber- } \\
\text { batu, } \\
\text { berkarang }\end{array}$ & 30 & $\begin{array}{l}\text { Pantai ber- } \\
\text { lumpur, terjal }\end{array}$ & 10 \\
\hline 2. & $\begin{array}{l}\text { Kedalaman } \\
\text { Perairan/Batimetri } \\
\text { (m) }\end{array}$ & $0-3$ & 30 & $>3-5$ & 20 & $>5$ & 10 \\
\hline 3. & Lebar Pantai (m) & $>10$ & 30 & $3-<10$ & 20 & $<3$ & 10 \\
\hline 4. & $\begin{array}{l}\text { Materi da- } \\
\text { sar/Sedimen } \\
\text { perairan }\end{array}$ & berpasir & 30 & $\begin{array}{l}\text { Pasir ber- } \\
\text { lumpur }\end{array}$ & 20 & $\begin{array}{l}\text { Berbattu, } \\
\text { lumpur }\end{array}$ & 10 \\
\hline 5. & $\begin{array}{l}\text { Kemiringan pan- } \\
\text { tai }(\%)\end{array}$ & $<8 \%$ & 30 & $>8-15 \%$ & 20 & $>15 \%$ & 10 \\
\hline 6. & $\begin{array}{l}\text { Kekeruhan } \\
\text { Perairan }\end{array}$ & $<400$ & 30 & $400-800$ & 20 & $>800$ & 10 \\
\hline 7. & $\begin{array}{l}\text { Penutup lahan pan- } \\
\text { tai }\end{array}$ & $\begin{array}{l}\text { Kelapa, la- } \\
\text { han terbuka }\end{array}$ & 30 & $\begin{array}{l}\text { Semak be- } \\
\text { lukar, sa- } \\
\text { vana }\end{array}$ & 20 & $\begin{array}{l}\text { Hutan bakau, } \\
\text { permukiman, } \\
\text { pelabuhan }\end{array}$ & 10 \\
\hline 8. & Biota berbahaya & Tidak ada & 30 & $\begin{array}{l}\text { Bulu babi, } \\
\text { lepu }\end{array}$ & 20 & Ikan pari, hiu & 10 \\
\hline 9. & $\begin{array}{l}\text { Ketersedian air } \\
\text { tawar (jarak/Km) }\end{array}$ & $<1$ & 30 & $1-2$ & 20 & $>2$ & 10 \\
\hline 10. & Panjang pantai (m) & $>300$ & 30 & $100-300$ & 20 & $<100$ & 10 \\
\hline
\end{tabular}

Sumber: Modifikasi dari Yulius 2008, Yuliana 2007, Bakosurtanal, 2007 dan Widiatmaka, 2007

\section{Keterangan:}

Skor 30 diberikan pada kategori S1 (Sesuai); skor 20: untuk kategori S2 (Sesuai Bersyarat); skor 10: untuk kategori N (Tidak Sesuai).

Sedangkan parameter yang Aksesibilitas, 8) Keterjangkauan, digunakan untuk menentukan prioritas 9)Kepedulian Masyarakat, 10) Kearifan pengembangan wisata pantai meliputi 12 Lokal, 11) Jaringan Komunikas, 12) aspek yaitu: 1) Jenis /Warna Pasir, 2) Tinggi Gelombang. Dari parameter Ketersediaan Lahan (Ha), 3) Sifat Air tersebut di skor.

Tanah, 4) Jumlah Mata Air, 5) Debit

Mata Air, 6) Sifat Mata Air, 7) 

Gambar 1. Diagram Alir Penelitian

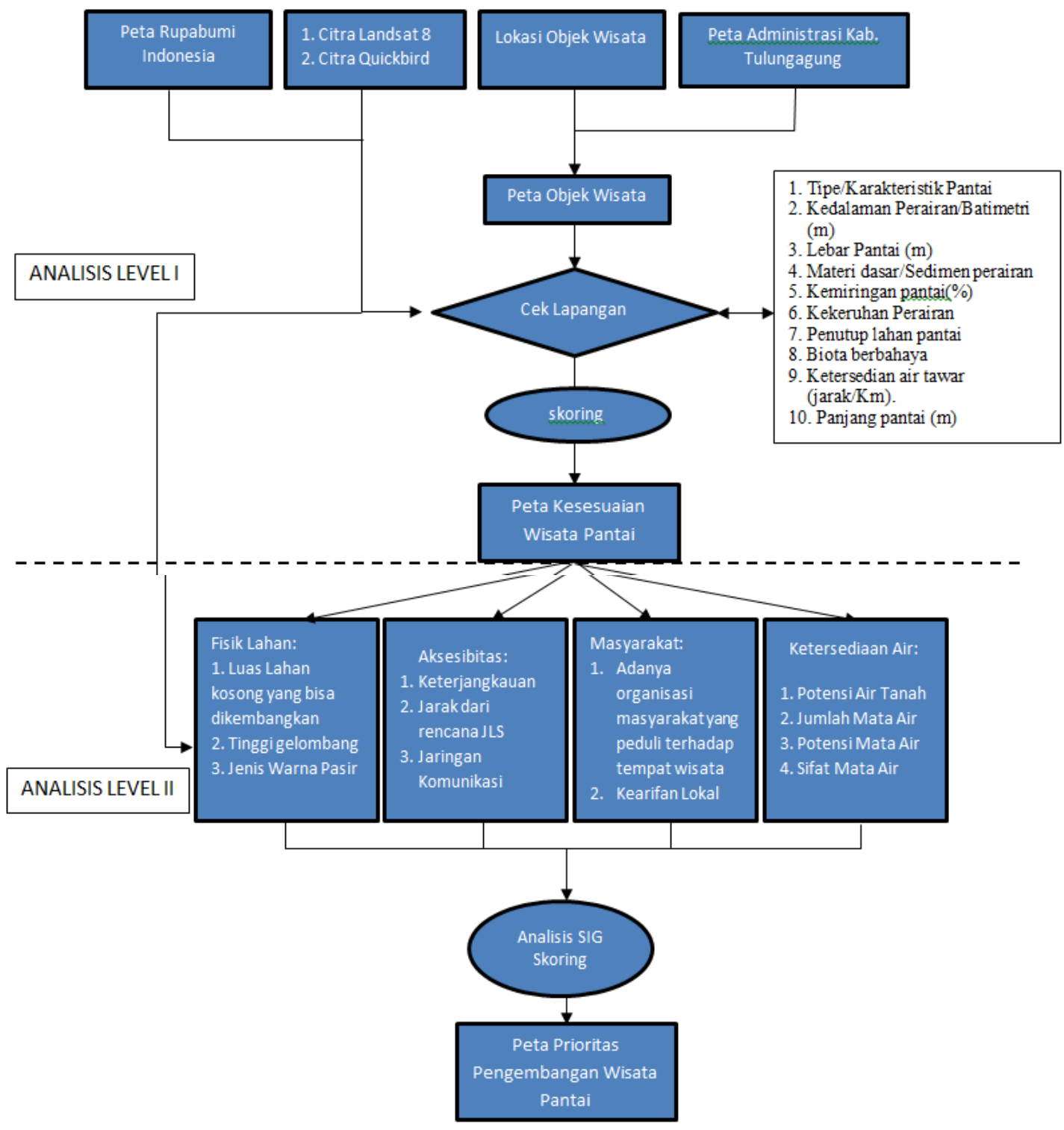

\section{HASIL DAN PEMBAHASAN}

\section{Analisis Kesesuaian Lahan}

Berdasarkan hasil analisis dengan

Sistem Informasi Geografi (SIG) dari 10 parameter kesesuan lahan untuk wisata pantai di kabupaten Tulungagung diperoleh tingkat kesesuaian sebagai tabel 2 berikut ini. 
Tabel. 2 Kesesuain lahan untuk wisata pantai di Kabupaten Tulungagung

\begin{tabular}{|c|c|c|c|c|c|c|c|c|c|c|c|c|c|}
\hline $\mathrm{NO}$ & $\begin{array}{l}\text { NAMA } \\
\text { PANTAI }\end{array}$ & SK1 & SK2 & SK3 & SK4 & SK5 & SK6 & SK7 & SK8 & SK9 & SK10 & $\begin{array}{c}\text { JUMLAH } \\
\text { SKOR }\end{array}$ & KESESUAIN \\
\hline 1 & $\mathrm{POPOH}$ & 20 & 30 & 20 & 10 & 30 & 30 & 10 & 30 & 20 & 20 & 220 & S2 \\
\hline 2 & MOLANG & 10 & 20 & 30 & 20 & 20 & 30 & 20 & 30 & 10 & 30 & 220 & S2 \\
\hline 3 & SIDEM & 30 & 20 & 30 & 20 & 20 & 20 & 10 & 30 & 30 & 30 & 240 & S1 \\
\hline 4 & KLATAK & 20 & 30 & 30 & 10 & 30 & 30 & 20 & 30 & 30 & 30 & 260 & $\mathrm{~S} 1$ \\
\hline 5 & GEMAH & 30 & 30 & 30 & 20 & 30 & 20 & 20 & 30 & 20 & 30 & 260 & S1 \\
\hline 6 & NGLARAP & 30 & 30 & 30 & 20 & 30 & 20 & 20 & 30 & 30 & 30 & 270 & S1 \\
\hline 7 & BRUMBUN & 30 & 30 & 30 & 30 & 30 & 20 & 10 & 30 & 30 & 30 & 270 & $\mathrm{~S} 1$ \\
\hline 8 & SINE & 30 & 30 & 30 & 30 & 30 & 30 & 10 & 30 & 20 & 30 & 270 & $\mathrm{~S} 1$ \\
\hline 9 & GERANGAN & 30 & 30 & 30 & 30 & 30 & 30 & 20 & 30 & 30 & 20 & 280 & $\mathrm{~S} 1$ \\
\hline 10 & BAYEM & 30 & 30 & 30 & 30 & 30 & 30 & 30 & 30 & 20 & 30 & 290 & S1 \\
\hline
\end{tabular}

\section{Keterangan:}

$\begin{array}{ll}\text { SK1 } & \text { : Tipe/Karakteristik Pantai } \\ \text { SK2 } & \text { : Kedalaman Perairan/Batimetri }(\mathrm{m}) \\ \text { SK3 } & \text { : Lebar Pantai }(\mathrm{m}) \\ \text { SK4 } & \text { : Materi dasar/Sedimen perairan } \\ \text { SK5 } & \text { : Kemiringan pantai }(\%) \\ \text { SK6 } & \text { : Kekeruhan Perairan } \\ \text { SK7 } & \text { :Penutup lahan pantai } \\ \text { SK8 } & \text { : Biota berbahaya } \\ \text { SK9 } & \text { : Ketersedian air tawar (jarak/Km). } \\ \text { SK10 } & \text { : Panjang pantai }(\mathrm{m})\end{array}$

Dari 10 lokasi wisata pantai di kabupaten Tulungagung terdapat 8 pantai yang memiliki tingkat kesesuain S1 yaitu tanpa faktor pembatas, sedangkan pantai yang tingkat kesesuaian S2 terdapat 2 pantai, dan tingkat kesesuain $\mathrm{N}$ (Marginal) tidak ada. Ini berarti bahwa pantai-pantai di Kabupaten Tulungagung Sesuai untuk dikembangkan untuk wisata pantai.

Dari 8 pantai yang memiliki kesesuain lahan S1 yaitu pantai Nglarap, Klatak, Bayem, Gemah, Sidem,
Brumbun, Nggerangan, dan Sine. Pantai tersebut tersebar di 3 Kecamatan yaitu Besuki, Tanggunggunung, dan Kalidawir. Pantai yang memiliki tingkat kesesuain S2 yaitu Pantai Popoh dan Pantai Molang.

Pantai yang memiliki potensi pengembangan pada tingkat S1 secara garis besar memenuhi daya dukung untuk wisata pantai. Sedangkan pantai Popoh dan Molang memiliki keterbatasan yang berbeda untuk dikembangkan. Pantai popoh merupakan pantai yang 
pertamakali dikembangkan di Kabupaten

Tulungagung. Namun pantai ini sekarang sudah banyak dimanfaatkan untuk permukiman dan Pelabuhan. Sedangkan lahan untuk pengembangan sangat terbatas. Berbeda dengan pantai Molang yang secara alamiah memiliki view panorama yang Bagus, namun lokasi sebagian besar lahan sudah dikembangkan sebagai kawasan tambak dan tidak tersedianya mata air.

Berdasarkan Tipologinya pantai di Kabupaten Tulungagung termasuk pantai
Land erosion coast, merupakan pesisir yang berkembang di bawah pengaruh erosi di daratan yang diikuti oleh proses inundasi oleh laut. Termasuk dalam kategori ini adalah lembah-lembah sungai, pesisir erosi glasial, dan pesisir pada topografi karstmenurut Shepard (King, 1972). Hal ini dapat dilihat dari morfologi pantai yang berupa semenanjung dan teluk dan disetiap pantai di control oleh adanya aliran sungai yang berada di lembah.

Gambar 2. Klasifikasi Genetik Pantai Primer Menurut Shepard, 1958 (dalam King, 1972).
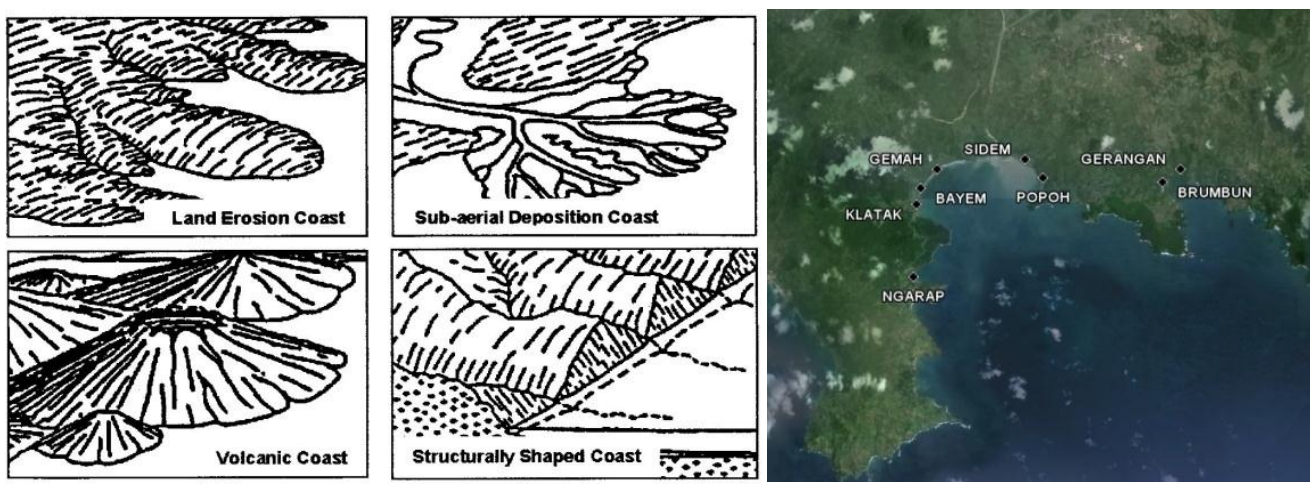


\section{Gambar 3. Peta Kesesuain lahan wisata pantai di kabupaten Tulungagung}

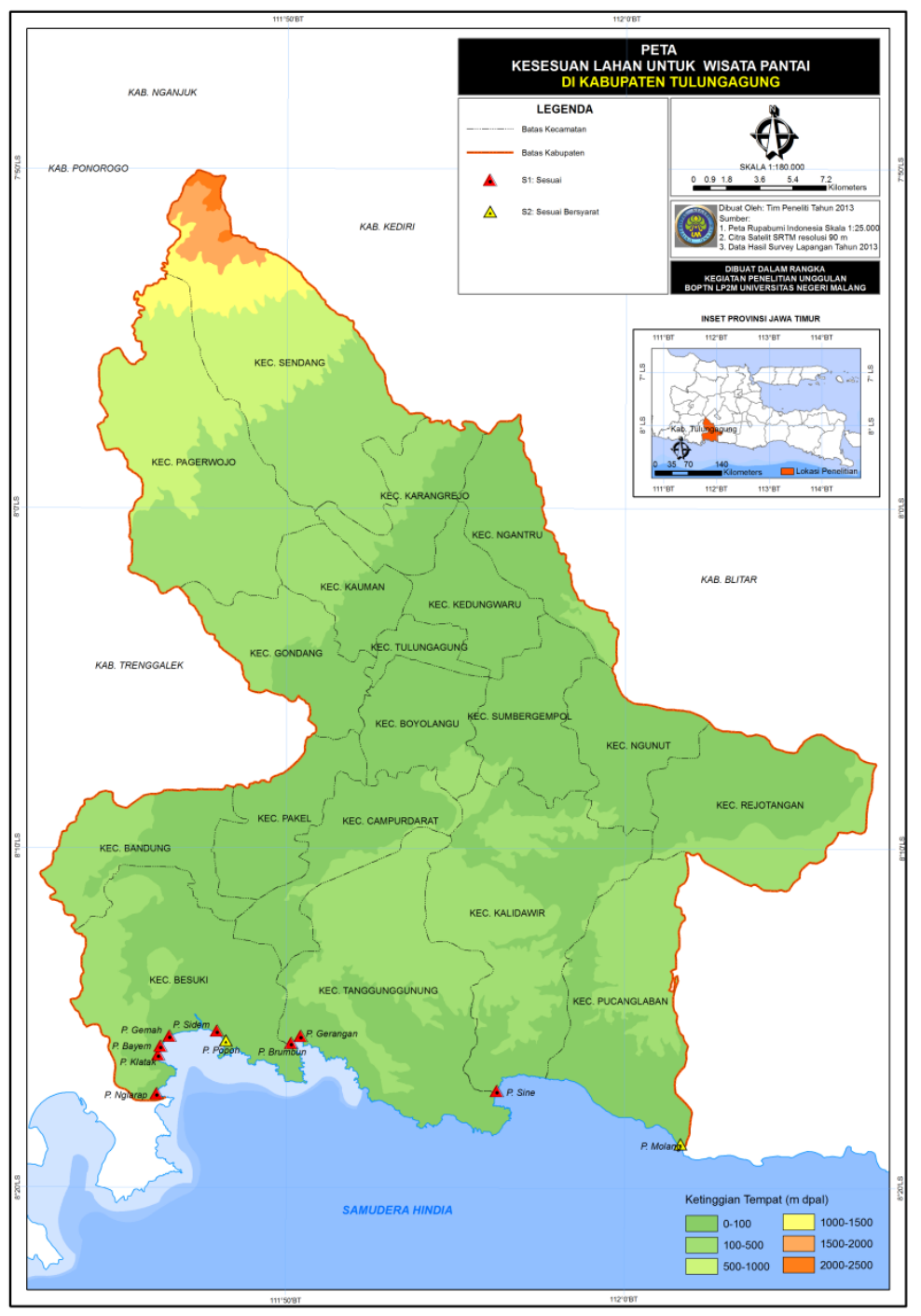

\section{Prioritas Pengembangan}

Pada analisis tahap I telah dihasilkan kesesuain lahan untuk wisata pantai di Kabupaten Tulungagung. Hasil tersebut ditindaklanjuti untuk mencari objek wisata yang dalam kategori sesuai (S1) untuk dicari prioritas pengembangannya. Aspek yang digunakan sebagai dasar penentuan prioritas yaitu 1) aspek aksesibilitas, 2) aspek potensi sumberdaya air, 3) aspek masyarakat, dan 4) aspek ketersediaan lahan terbuka. Hasil analisis skoring tersebut disajikan dalam Tabel 3 berikut ini. 
Tabel 3. Hasil analisis Prioritas Pengembangan Pantai dengan SIG

\begin{tabular}{|c|c|c|c|c|c|c|c|c|c|c|c|c|c|c|}
\hline NAMA_PANTAI & SK1 & SK2 & SK3 & SK4 & SK5 & SK6 & SK7 & SK8 & SK9 & SK10 & SK11 & SK12 & $\begin{array}{c}\text { JUMLAH } \\
\text { SKOR }\end{array}$ & PRIORITAS \\
\hline BAYEM & 25 & 30 & 15 & 20 & 20 & 25 & 30 & 30 & 20 & 25 & 20 & 30 & 290 & P1 \\
\hline KLATAK & 15 & 30 & 15 & 20 & 25 & 25 & 30 & 30 & 20 & 30 & 15 & 20 & 275 & P1 \\
\hline GERANGAN & 30 & 10 & 15 & 25 & 30 & 25 & 20 & 20 & 30 & 25 & 10 & 20 & 260 & $\mathrm{P} 1$ \\
\hline SIDEM & 20 & 15 & 30 & 15 & 15 & 10 & 30 & 30 & 20 & 15 & 25 & 15 & 240 & P2 \\
\hline BRUMBUN & 25 & 10 & 25 & 15 & 20 & 15 & 20 & 20 & 30 & 15 & 10 & 20 & 225 & P3 \\
\hline SINE & 20 & 30 & 15 & 20 & 20 & 15 & 15 & 20 & 20 & 25 & 10 & 15 & 225 & P3 \\
\hline NGLARAP & 15 & 25 & 15 & 20 & 15 & 15 & 30 & 15 & 10 & 15 & 15 & 25 & 215 & P3 \\
\hline GEMAH & 20 & 20 & 15 & 15 & 15 & 15 & 25 & 20 & 10 & 10 & 15 & 15 & 195 & P3 \\
\hline
\end{tabular}

Keterangan:

SK1 : Jenis /Warna Pasir

SK2 : Ketersediaan Lahan (Ha)

SK3 : Sifat Air Tanah

SK4 : Jumlah Mata Air

SK5 : Debit Mata Air

SK6 : Sifat Mata Air

SK7 : Aksesibilitas

SK8 : Keterjangkauan

SK9 : Kepedulian Masyarakat

SK10 : Kearifan Lokal

SK11 : Jaringan Komunikasi

SK12 : Tinggi Gelombang

Berdasarkan hasil analisis tahap II ini pantai Sidem, dan Prioritas dihasilkan objek wisata yang memiliki pengembangan ke III yaitu pantai prioritas untuk dikembangkan. Prioritas Brumbun, Sine, Gemah dan Nglarap. pengembangan I yaitu pantai Bayem, Sebaran pantai secara spasial dapat dilihat Klatak dan Pantai Nggerangan, pada gambar peta berikut ini. sedangkan prioritas pengembagan ke II

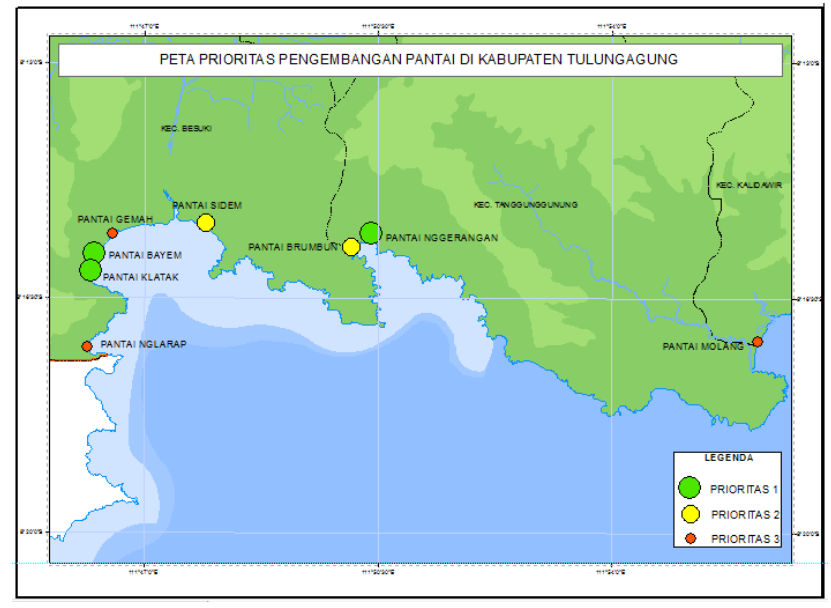


Gambar 4. Sebaran Prioritas Penembangan Pantai di Kabupaten Tulungagung dengan SIG.

Terpilihnya pantai Bayem, Klatak, dan Gerangan, ketiga pantai ini memiliki skor tertinggi dari lima pantai lainnya yaitu 290, 275 dan 260. Ketiga pantai tersebut memiliki karakteristik keunggulan masing jika dibanding dengan pantai lainnya.

Pantai Bayem meliki kelebihan lahan yang relatif masih terbuka dan viem yang bagus, dan pantai Bayem meliki akasesis yang mudah untuk dijangkau olehsemua kendaraan, jaringan komunikasi mudah.

Pantai Klatak memiliki karakteristik pantai yang berupa batu kali yang tersusun secara teratur oleh gelombang, sehingga memunculkan daya tarik tersendiri ketika terkena hempasan gelombang akan bernbunyi "Klatakklatak". Pada pantai ini juga terdapat aumber air tawar yang muncul di laut, ini merupakan potensi tersendiri jika dapat dikembangkan secara maksimal. Selain objek tersebut pantai Klatak juga memiliki Gua yang namanya Gua Glogok. Gua ini ketika air laut surut dapat digunakan sebagai akses jalan menuju pantai Bayem yang hanya berjarak 50 meter yang terpisah oleh bukit terjal.

Pantai Ketiga yaitu pantai Gerangan, pantai ini terletak di Kecamatan Tanggung Gunung. Kelebihan pantai ini jika dibandingkan dengan pantai lainnya yaitu tersedianya sumber air yang cukup melimpah baik musim penghujan maupun kemarau tidak pernah terganggu. Selain itu Masyarakat di Pantai Gerangan sangat peduli terhadap lingkungan pantai. Bentuk aktivitas nyata adalah adanya organisasi POK MAS yaitu kelompok masyarakat. Aktivitas yang dilakukan secara rutin adalah membersihkan lingkungan pantai setiap minggunya. 


\section{KESIMPULAN}

Berdasarkan hasil penelitian maka dapat disimpulkan Pantai di Kabupaten Tulungagung memiliki tingkat kesesuaian untuk wisata pantai pada tingkat S1 (sesuai) yang meliputi Pantai Bayem, Sidem, Gemah, Klatak, Sine, Nglarap, Brumbun, dan Gerangan. Sedangkan pantai yang memiliki kesesuain lahan untuk wisata pantai S2 (sesuai dengan faktor pembatas) yaitu pantai Popoh dan Pantai Molang. Dari hasil kajian penentuan prioritas pengembangan wisata pantai Pantai Bayem, Klatak, dan Nggerangan memiliki prioritas pertama untuk dikembangkan sesuai dengan karakteristiknya.

\section{DAFTAR RUJUKAN}

Astina, I komang, Purwanto, dan Yusuf S. 2013. Potensi Dan Pengembangan Daerah Tujuan Wisata Pantai Kabupaten Tulungagung Menggunakan Analisis Keruangan, SWOT, Dan SIG. Malang: Lembaga Penelitian dan Pengabdian Kepada Masyarakat (LP2M).

Baiquni, M. 2004. Wisata Bahari Sulawesi (Potensi, Problem, dan Prospek). Yogyakarta: Badan Penerbit Fakultas Geografi UGM.
Bappeda Kabupaten Tulungagung. 2012. Tulungagung dalam Angka (tidak dipublikasikan)

CERC (Coastal Engineering Research Center). 1984 Shore Protection Manual. Vol. I, Dept. of Army, Washington, D.C.

Gede Pitana dan Ketut Surya Diarta. 2009. Pengantar Ilmu Pariwisata. Yogyakarta: Penerbit Andi.

Hardjowigeno, Sarwono dan Widiatmaka. 2007. Evaluasi kesesuain lahan dan perencanaan Tataguna lahan. Yogyakarta: Gadjah Mada University Press.

Poniman, Aris. 2004. Survey dan Pemetaan Tipologi Pesisir Indonesia. Yogyakarta: Bakosurtanal-Fakultas Geografi UGM.

Pramono, Gatot $\mathrm{H}$ dan Suwahyuono. 2004. Prospek Penggunaan ObjectOriented untuk Datas Spasial Di Wilayah Pesisir dan Laut. Yogyakarta: Bakosurtanal-Fakultas Geografi UGM.

Purwanto, 2006. Penginderaan Jauh Untuk Pengelolaan Pesisir dan Kelautan. Yogyakarta: Jurusan Geografi UGM.

Yulius, 2008. Aplikasi Sistem Informasi Geografis Dalam Penentuan Kawasan Wisata Pantai Kategori Rekreasi Di Teluk Bungus, Kota Padang. Jakarta: Pusat Riset Wilayah Laut dan Sumberdaya Nonhayati, BRKP - DKP. 